\begin{abstract}
Iranica
Abstracta Iranica Revue bibliographique pour le domaine irano-aryen

Volume 34-35-36 | 2017

Comptes rendus des publications de 2011-2013
\end{abstract}

\title{
Pierre-Louis Gatier. Des Péliganes à Suse
}

\section{Rémy Boucharlat}

\section{OpenEdition}

Journals

Édition électronique

URL : http://journals.openedition.org/abstractairanica/41801

DOI : 10.4000/abstractairanica.41801

ISSN : 1961-960X

Éditeur :

CNRS (UMR 7528 Mondes iraniens et indiens), Éditions de l'IFRI

\section{Référence électronique}

Rémy Boucharlat, «Pierre-Louis Gatier. Des Péliganes à Suse », Abstracta Iranica [En ligne], Volume 34-35-36 | 2017, document 17, mis en ligne le 30 décembre 2016, consulté le 27 septembre 2020 URL : http://journals.openedition.org/abstractairanica/41801; DOI : https://doi.org/10.4000/ abstractairanica.41801

Ce document a été généré automatiquement le 27 septembre 2020.

Tous droits réservés 


\title{
Pierre-Louis Gatier. Des Péliganes à
}

\section{Suse}

\author{
Rémy Boucharlat
}

\section{RÉFÉRENCE}

Pierre-Louis Gatier. « Des Péliganes à Suse ». Zeitschrift für Papyrologie und Epigraphik 184,2013 , p. 205-210.

Dans son article sur le bilinguisme dans l'Orient post-alexandrin, G. Rougemont (« Les inscriptions grecques d'Iran et d'Asie centrale. Bilinguismes, interférences culturelles, colonisation », Journal des Savants, janvier-juin 2012) publiait dans un « Post-scriptum: encore une inscription de Suse? " qui ne lui était pas connu à l'achèvement de son corpus des Inscriptions grecques. C'est une stèle calcaire brisée portant de 10 lignes très incomplètes, trouvée à Eyvān-e KarHुe, près de Suse. Il suggérait d'y reconnaître un décret civique sans doute du IIe s. av. n. è et apporté depuis Suse des siècles plus tard. P.-L. G. propose d'y voir le témoignage de l'existence, sans doute à Suse, d'un conseil de " péliganes ", un conseil d'anciens, institution typiquement macédonienne qui renforce l'image de l'hellénisation des institutions de la ville.

\section{AUTEURS}

\section{RÉMY BOUCHARLAT}

\author{
CNRS, Lyon
}

